\title{
The Research on Current Situation and Countermeasure of University Science Park in Gulou District of Nanjing, China
}

\author{
Songqiang $\mathrm{Wu}^{*}$, Xiao Xiao, Wang Lu, Xingyi Shen, Xianting Tao \\ School of Economics and Management, Nanjing University of Technology, Nanjing, China

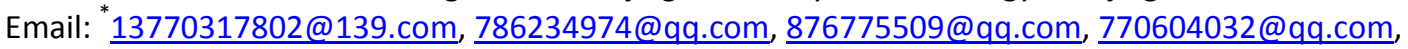 \\ 717421525@qq.com
}

Received 15 February 2015; accepted 16 April 2015; published 21 April 2015

Copyright @ 2015 by authors and Scientific Research Publishing Inc.

This work is licensed under the Creative Commons Attribution International License (CC BY). http://creativecommons.org/licenses/by/4.0/

cC) (7) Open Access

\begin{abstract}
So far, the development of State University Science Park has become important force to promote regional economy development. This paper theoretically makes judgment over the effects of regional economy development of State University Science Park. Thus, taking State University Science Park of Gulou District in Nanjing as an example, the paper respectively elaborated the influence of State University Science Park on regional economic brands, services and information from the aspects of brand building, technology trade, and scientific and technical activities undertaking. In order to further improve and popularize the practices of State University Science Park of Gulou District in Nanjing, the paper proposed the corresponding policy inspiration: constantly stuck to the law of economic development and innovated the service function and approaches; made use of science and technology entering the park to organize innovation union to promote the capacity of regional scientific and technical innovation and broke the bottleneck of State University Science Park development to provide the regional economy with sustainable service.
\end{abstract}

\section{Keywords}

University Science Park, Research, Countermeasure, Recommendation

\section{Introduction}

Based on the advantages resources of knowledge and innovative environment of University Science Park, and combined with social funds, management and market demand, national university science park drives the de-

*Corresponding author. 
velopment of regional economy, and has become an important part of national innovation system, since it is an important national science and technology innovation base, a high-tech enterprises incubation base, a innovation and entrepreneurship gathering and training base, an industry and academy combination pilot base.

Generally believed, State University Science Park relies on universities or college groups and makes the most of universities' advantages such as personnel, technology, information, laboratory equipment, culture and so on. With the guidance and the support of government, it focuses on technology innovation and business incubation activities through diverse investment channels including venture capital.

\section{Literature Review}

Nowadays, University Science Park has been recognized to have an important role as one of the project key processes. Furthermore, State University Science Park is a widely researched topic in the area of university project. Prior research on University Science Park has primarily focused on the function of Science Park as well as on the influence of development. Yu Anping think through the establishment of virtual University Science Park and the implement of multipoint Science Park, University Science Parks will have incubative and radiative effects on regional economic and social development [1]. Ye Fu and Qiang Ma dictate that the local government plays an active role in promoting University Science Park and points out the local government should define itself as an actively responsible stage-builder who constitute the programs and carry them out, optimize the entrepreneurial environment and create the cultural atmosphere of innovation [2]. Qiufeng Wu and Huaian Wei discuss the function of University Science Park from the interaction of the university and environment and he points out the function and the mission of it is different from other common organization. Based on the strategic goal of national innovation, they also analyze the evolvement path of innovation of University Science Park [3]. Xiaofang Tan and Xingyu Zhu divide functions of University Science Park into basic function, general function and special function which will change in practical development. Taking Nanchang University Science Park as an example [4], Jin Xia and Jin Tu maintain that University Science Parks (USP) provide an effective pattern to promote synergy creation of production, learning and research, industrial revitalization, and regional economic development. The USPs support and organizational mode should be different as the differences between the cycle of transformation of S\&T achievement and the life cycle of corporation [5]. Ping Li defines University Science Park's organizational characteristics as innovation, service, dependence and buffer. Its basic functions are the innovation of R\&D, the incubation of enterprises and the cultivation of talents, among which the incubation of enterprises is the key function [6]. Maura McAdama and Rodney McAdam use 18 high technology business firms (spin out HTBFs) within two separate University Science Park Incubators (USIs) to explore the longitudinal use of the unique resources of the USI by HTBFs at different lifecycle stages [7]. Chunlin Liu and Jisheng Peng introduce the development situation of University Science Parks of US, British and Japan, and draws the reveal to University Science Parks of China from four aspects: government support, capital formation, services system and construction of professional University Science Parks [8]. Yin Qun, Xie Yun and Weimin Chen use the method of regression to analyze the impacts of preferential policies for the incubation performance of University Science Park. They think that principal effect is the financing police and that the effects of rent policy as well as fiscal and tax policy are subordinate [9]. Based on the investigation of university-based science parks in the Zhongguangcun area, Wei Zhang finds that the exterior management innovation and interior market operation are the key factors to the success of University Science Park, based on an empirical study on the State Science Park of Nanjing University [10]. Lin Li, Dongdong Xia and Yongning Wang construct the evaluation system of Chongqing science and technology parks through AHP, which provides the basis for accelerating the effective combination of industries, universities and research institutes, optimizing the allocation of resources of University Science Parks [11].

\section{Progress of the Research}

\subsection{Subjects and Methods of the Research}

Through interviews and questionnaires, we collected complete information about 6 State University Science Parks' situation. These universities include: the national university science park of Nanjing University and Colleges in Gulou District, Nanjing Tech University National Science Park, Southeast University Science Park (Dingjiaqiao Campus), Nanjing University of Financial and Economic Science Park, Science and Technology 
Park of Nanjing University of Chinese Medicine Science Park, Nanjing University of Posts and Telecommunications Science Park. There were nearly 200 people interviewed. And 80 questionnaires are sent to enterprises and recycled 51 . The recovery rate is $76.25 \%$. And university science parks also receive 6 questionnaires. The data of this report are all from questionnaires.

\subsection{Purpose of the Research}

The purpose of this research is to strengthen independent innovation, to promote the economy which is based on the innovation, to shift about economic development mode and to speed up regional economic transformation. As a result, we can offer suggestions to the district government about how to make University Science Park a sustained rapid and sound development.

\section{Progress of the Research}

\subsection{General Situation of University Science Parks in Gulou District}

The total gross leasable area of six university science parks in use is 850,000 square meters. Area under construction is 340,000 square meters and planning area is 1,060,000 square meters. There are 63 staffs of science parks. The number of incubated technology enterprises was 895 in 2009, whose total revenue was 6.82 billion Yuan. The total number of accumulative graduated enterprises was 137, whose total revenue was 4.64 billion Yuan. The number of staffs who worked for incubating enterprises was 7939, while that of new incubating enterprises was 45.

In the past three years, there were 166 proprietary products, 1102 patents in university science parks. The total operating income of 6 university science parks reached 12.4 million Yuan nearly in three years. Over the past three years, there have already made 87 scientific and technological achievements at provincial and ministerial level.

\subsection{Individual Situation of Six Science Parks in Gulou District}

1) The national university science park of Nanjing University and Colleges in Gulou District

The national university science park of Nanjing University and Colleges in Gulou District is one of the first national science parks identified by Ministry of Education and Science in May 5, 2001. The park is established by 9 universities and Gulou district government together. These universities include Nanjing University, Hohai University, China Pharmaceutical University, Nanjing Normal University, Nanjing Post and Telecommunications University, Nanjing Medical University, Nanjing Tech University, Nanjing University of Chinese Medicine, Nanjing Institute of Technology. Effectively cooperated with each other, governments, scientific research institutions, enterprises and markets, universities can take good use of their complementary resources. The Science Parks mainly include five industries, namely electric power automation industry, urban rail transportation industry, wireless communications R\&D industry and biology medicine R\&D design industry.

2) National University Science Park of Southeast University

The National University Science Park of Southeast University was established in May, 2001, one of the first 15 experimental awarded by Ministry of Science and Technology and the Ministry of Education. After nine-year construction, it has built 5 parks whose incubation area is 50,000 square meters. Currently, there are 200 enterprises in it. 102 of them are incubating enterprises, while over $90 \%$ of the enterprises are technology enterprises recognized by the state, the province and the city. The industry fields of the enterprises in the parks includes: mobile communications technology and products, display technology and terminal products, computer network, software technology and products, bio-genetic technology and products, environmental protection technology and products, etc. The total production value of enterprises in these parks reached 450 million Yuan, which mainly are the technology enterprises equity participated by Southeast University, and achieved the profit of 130 million Yuan.

3) Nanjing University of Financial and Economic Science Park

Nanjing University of Financial and Economic Science Park is a high-tech industrial park based on finance, economics and information construction, serving for modern service industry. The objective of it is to integrate three functions, R\&D, incubation and congregation of modern service industry as a whole. The Science Park plans to cover an area of over $100 \mathrm{Mu}$, which divides into two blocks, the technology innovation park and the technology industrial park. Currently, the Science Park plans to build the first period of the project, covers a total building area of nearly 50,000 square meters. 
4) Nanjing University of Chinese Medicine Science Park

Jiangsu Provincial Science \& Technology Department and Education Department approved Nanjing University of Chinese Medicine and Nanjing Gulou District Municipality People's Government to jointly construct Provincial University Science Park of NUCM in the Hanzhong Gate Campus on December 4th, 2009. Relying on the strong scientific research capability and professional teachers of NUCM, the Science Park will become the integrated place of advanced technology and information of Chinese Medicine, the R\&D innovation base of Chinese Medicine, the place had been well known as world and national famous Chinese Medicine R\&D units, and the window of external communication for Nanjing Pharmaceutical industry.

5) IOT (The internet of things) Science Park of Nanjing University of Post and Telecommunications

IOT (The internet of things) Science Park of NUPT (Nanjing University of Posts and Telecommunications) is a university technology innovation park which is jointly constructed with the government of Nanjing Gulou District. The Construction and Management committee of the Science Park take full responsibilities of the planning, construction, operation and management of the IOT (The internet of things) Science Park of NUPT. In August, 2010, Nanjing IOT industry research institution, Nanjing IOT technology and application research institution, IOT Science Park of NUPT, Nanjing IOT application and service Demonstration Park and Nanjing IOT industry Alliance established at Nanjing IOT conference simultaneously.

6) Nanjing Tech University National Science Park

Nanjing Tech University National Science Park is located in the campus of New Model Street. At present, there are about 140 scientific and technological enterprises have entered into the scientific and technological building, including about 40 enterprises which cooperate to establish R\&D center with universities. The enterprises which have come into the park ranged over a number of fields: computer and telecommunication, energy and traffic, new materials and equipment, mechatronics, architecture and environment and so on. Incubation projects have a high technological level and a good market prospect.

Based on the investigation and research, the six national University Science and Technology Parks which I mentioned before will be executed in the following Table 1 .

\section{Analysis of the Research}

The condition of University Science Park is very complex now, due to varied construction subjects and patterns, involving government, universities, social enterprises, etc. Hindered management systems and operating mechanisms have bad affects on the development of Park of Gulou District.

\subsection{Excessive Intervention of Government on Management}

The managers from universities make most of the developmental strategic decisions of State University Science Park instead of managers from science parks. Science park management institutions are organizations which have administrative, serving and other operational functions. In addition, universities and governments work out many management methods, but do not put them into practice.

The model of the national university science park of Nanjing University and Colleges in Gulou District is "Many universities with one Park". Universities inside the park appear united outwardly but work separated. Because of the hindered management systems and the poor operating resources, University Science Park grow slowly.

\subsection{Unsatisfactory Financial Resources}

According to questionnaire data analysis, Figure 1 describes that the percentage of financial resources of University Science Park from questionnaire collection. Besides, we got seven points form data collection summary. You could see that the first three kinds of "The financial resources of University Science Park" are as follows: "Rental housing" accounts for $20 \%$, "Government grant" accounts for $18 \%$ and "Transformation of achievements" occupies $14 \%$. We can see that many parks rely mainly on housing rental income. The income of transformation of achievements and the reward of enterprises incubation contribute little to the parks. Many enterprises of the park transmit to another place in industrially after graduation or put the research centers in the park and have been industrialized in other place. Some of the typical research responses are shown in Figure 1.

From current situations, it is difficult to make profit if University Science Park considers incubating Hi-tech enterprises as their only tasks. If University Park only relies on location rental of the park and the offering service 
Table 1. The comparison of the six national university science and technology parks.

\begin{tabular}{|c|c|c|c|c|c|c|}
\hline Name & $\begin{array}{c}\text { National University } \\
\text { Science and } \\
\text { Technology } \\
\text { Park of Nanjing } \\
\text { University-Universities } \\
\text { of Gulou }\end{array}$ & $\begin{array}{l}\text { National University } \\
\text { Science and } \\
\text { Technology Park } \\
\text { of Nanjing } \\
\text { University of } \\
\text { Technology }\end{array}$ & $\begin{array}{c}\text { National } \\
\text { University } \\
\text { Science and } \\
\text { Technology Park } \\
\text { of Southeast } \\
\text { University }\end{array}$ & $\begin{array}{c}\text { University } \\
\text { Science and } \\
\text { Technology Park } \\
\text { of Nanjing } \\
\text { University of } \\
\text { Finance \& } \\
\text { economics }\end{array}$ & $\begin{array}{c}\text { University } \\
\text { Science and } \\
\text { Technology } \\
\text { Park of } \\
\text { Nanjing } \\
\text { University } \\
\text { of Chinese } \\
\text { Medicine }\end{array}$ & $\begin{array}{c}\text { University Science } \\
\text { and Technology Park } \\
\text { of Nanjing University } \\
\text { of Posts and } \\
\text { Telecommunications }\end{array}$ \\
\hline $\begin{array}{l}\text { Construction } \\
\text { Feature }\end{array}$ & $\begin{array}{l}\text { High-tech enterprises } \\
\text { incubation }\end{array}$ & $\begin{array}{l}\text { Cooperation of } \\
\text { Industry, } \\
\text { Academe and } \\
\text { Research Institutes }\end{array}$ & $\begin{array}{c}\text { Transfer of existing } \\
\text { scientific and } \\
\text { technological } \\
\text { achievements }\end{array}$ & - & - & - \\
\hline $\begin{array}{l}\text { Functional } \\
\text { Orientation }\end{array}$ & $\begin{array}{l}\text { High-tech enterprises } \\
\text { incubation, transfer } \\
\text { of existing scientific } \\
\text { and technological } \\
\text { achievements, } \\
\text { cultivation of } \\
\text { high-quality } \\
\text { creative and } \\
\text { pioneering talents }\end{array}$ & $\begin{array}{l}\text { Cooperation of } \\
\text { Industry, } \\
\text { Academe and } \\
\text { Research Institutes, } \\
\text { transfer of existing } \\
\text { scientific and } \\
\text { technological } \\
\text { achievements, } \\
\text { cultivation of } \\
\text { high-quality creative } \\
\text { and pioneering talents }\end{array}$ & $\begin{array}{l}\text { Cooperation of } \\
\text { Industry, } \\
\text { Academe and } \\
\text { Research Institutes, } \\
\text { transfer of existing } \\
\text { scientific and } \\
\text { technological } \\
\text { achievements }\end{array}$ & $\begin{array}{l}\text { Cultivation of } \\
\text { high-quality } \\
\text { creative and } \\
\text { pioneering talents }\end{array}$ & - & $\begin{array}{l}\text { Cooperation of } \\
\text { industry, } \\
\text { academe and } \\
\text { research institutes, } \\
\text { transfer of existing } \\
\text { scientific and } \\
\text { technological } \\
\text { achievements }\end{array}$ \\
\hline $\begin{array}{l}\text { Development } \\
\text { Model }\end{array}$ & $\begin{array}{l}\text { Nine universities one } \\
\text { park, cooperation of } \\
\text { universities and districts }\end{array}$ & $\begin{array}{c}\text { One university } \\
\text { one park }\end{array}$ & $\begin{array}{l}\text { One university } \\
\text { One park }\end{array}$ & $\begin{array}{l}\text { One university } \\
\text { one park, } \\
\text { cooperation of } \\
\text { universities and } \\
\text { districts }\end{array}$ & $\begin{array}{l}\text { One university } \\
\text { one park, } \\
\text { cooperation } \\
\text { of universities } \\
\text { and districts }\end{array}$ & $\begin{array}{l}\text { One university } \\
\text { one park, } \\
\text { cooperation of } \\
\text { universities and } \\
\text { districts }\end{array}$ \\
\hline $\begin{array}{l}\text { Operational } \\
\text { Mechanism }\end{array}$ & $\begin{array}{c}\text { Managing Committee } \\
\text { Office }\end{array}$ & $\begin{array}{l}\text { Managing Committee } \\
\text { Office/Science and } \\
\text { Technology Park, } \\
\text { mixing management } \\
\text { and administration } \\
\text { of the corporation }\end{array}$ & $\begin{array}{c}\text { Managing } \\
\text { Committee } \\
\text { Office/Science } \\
\text { and Technology } \\
\text { Park, mixing } \\
\text { management and } \\
\text { administration } \\
\text { of the corporation }\end{array}$ & $\begin{array}{c}\text { Managing } \\
\text { Committee } \\
\text { Office/Science } \\
\text { and Technology } \\
\text { Park, mixing } \\
\text { management } \\
\text { and administration } \\
\text { of the corporation }\end{array}$ & $\begin{array}{c}\text { No } \\
\text { administration }\end{array}$ & $\begin{array}{l}\text { Construct Managing } \\
\text { Committee Office }\end{array}$ \\
\hline $\begin{array}{c}\text { Present } \\
\text { Difficulties }\end{array}$ & $\begin{array}{l}\text { Lack of controlled } \\
\text { space carrier }\end{array}$ & $\begin{array}{l}\text { Lack of policy } \\
\text { support ,such as } \\
\text { the tax (Enterprises } \\
\text { of Science Park, } \\
\text { incubated enterprises) }\end{array}$ & $\begin{array}{c}\text { Planning and } \\
\text { coordination (the } \\
\text { land, funds, } \\
\text { capital construction) }\end{array}$ & $\begin{array}{l}\text { Planning and } \\
\text { coordination } \\
\text { (land question) }\end{array}$ & $\begin{array}{l}\text { It has not } \\
\text { reached a } \\
\text { consensus } \\
\text { on main } \\
\text { thought of } \\
\text { building } \\
\text { science park }\end{array}$ & Tempo propulsion \\
\hline $\begin{array}{l}\text { Anticipated } \\
\text { Work }\end{array}$ & $\begin{array}{l}\text { Nanjing University } \\
\text { makes } 5000 \text { square } \\
\text { meters room to make } \\
\text { accelerator }\end{array}$ & $\begin{array}{l}\text { Integrate Hongqiao } \\
\text { Campus, } \\
\text { Construction of } \\
\text { C \& D building, } \\
\text { implement } \\
\text { preferential } \\
\text { policies, start the } \\
\text { low-carbon } \\
\text { industrial } \\
\text { research institute }\end{array}$ & $\begin{array}{l}\text { Develop the } \\
\text { Dingjiaqiao } \\
\text { Campus, } \\
\text { construct the } \\
\text { branch of } \\
\text { Southeast } \\
\text { University }\end{array}$ & $\begin{array}{l}\text { Develop the Fujian } \\
\text { Road Campus, } \\
\text { construction of } \\
\text { first project for } \\
\text { 50,000 square } \\
\text { meters }\end{array}$ & $\begin{array}{l}\text { Develop the } \\
\text { Hanzhongmen } \\
\text { Campus, } \\
\text { define rental } \\
\text { housing or the } \\
\text { construction } \\
\text { plan of } \\
\text { technological } \\
\text { house }\end{array}$ & $\begin{array}{l}\text { Develop the Mofan } \\
\text { Road Campus, } \\
\text { Vacate main } \\
\text { teaching } \\
\text { building, Build the } \\
\text { exhibition hall }\end{array}$ \\
\hline
\end{tabular}

Data sources: from questionnaires survey and collection. See the Appendix. 
The financial resourses of University Science Park
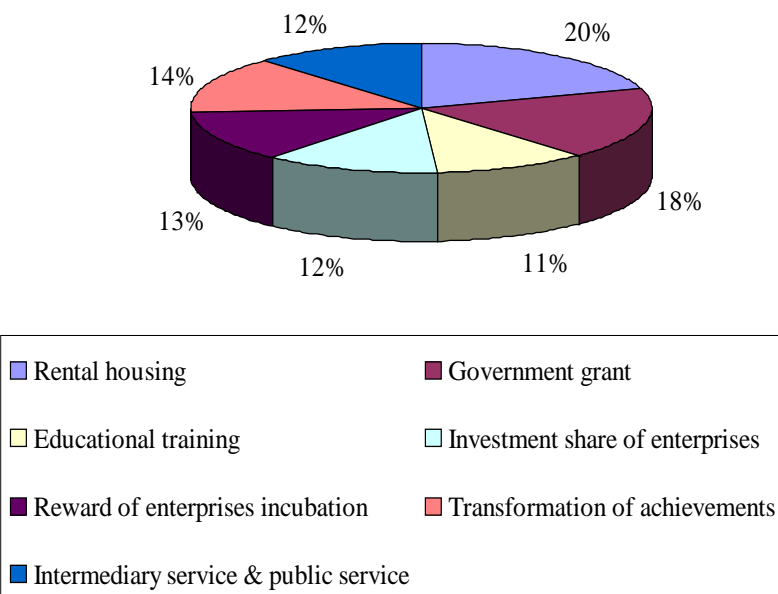

Figure 1. The financial resources of university science park. (Data sources: from questionnaire survey and collection. See the Appendix for more details).

income, it will face problems in development. It is difficult to receive a good achievements if university science park only exists on subsidy from the government and operating in the way of institutional unit which must be impaired its vitality.

\subsection{Imperfect Mechanism of Talent Motivation and Movement}

According to present management system, university teachers are not allowed to engage in technology transfer. Because of the stable treatment, many scientific researchers are unwilling to leave their positions and abandon a steady job. This kind of imperfect talent inspiriting mechanism usually deflates scientific researcher's enthusiasm. And it strongly influences cooperation of the industry, academe and research institutes. Their achievements in scientific research can't exert their expected market potentiality.

Figure 2 describes that the percentage of difficulties of Industry, Academe and Research Institutes Cooperation from questionnaire collection. As you know, we also made seven points form data collection summary. You could see that "University scientific research system is restricted and the benefit allocation of Industry, Academe and Research Institutes is too difficult" take the most parts in the current circumstance, accounting for $33 \%$. Secondly, "The innovative consciousness of enterprises is weak and the enterprises have not enough R\&D funds" and "Lack of government policy and risk investment" account for $18 \%$ respectively. Some of the typical research responses are shown in Figure 2.

\subsection{Uncompleted Service System and Service Platform}

The service provided by most parks mainly is share service, such as property management, commercial tax registration, the training of related knowledge and so on. But science parks don't offer professional technological service which can reflect more strength of the Park. Because of the imperfect service system, the incubation capability of University Science and Technology Park is limited.

Figure 3 describes that "the Factors of Attract Enterprise Immigrate University Science Park" from questionnaire collection. And we get six points form data collection summary. You could see that taking the most parts is "Comprehensive intermediary service and public service", accounting for $24 \%$. Next is "Huge university innovative achievement" and "Nice researching environment and superior conditions", accounting for $18 \%$ respectively. From this, we can see that public service system is critical to the attraction of the enterprises in Park. Some of the typical research responses are shown in Figure 3. 


\section{Difficulties of Industry, Academe and Research Institutes Cooperation}

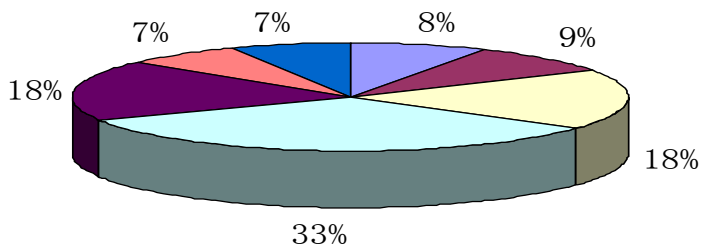

$\square$ Lack of valuable research results

$\square$ The intermediary capability and the level of scientific intermediary organizations are undeveloped

$\square$ The innovative consciousness of enterprises is weak and the enterprises have not enough R\&D funds

$\square$ University scientific research system is restricted and the benefit allocation of Industry, Academe and Research Institutes is too difficult

$\square$ Lack of government policy and risk investment

$\square$ The index system of enterprise evaluation is defective

$\square$ Large enterprises have monopolized the techniques and product technology

Figure 2. Difficulties of industry, academe and research institutes cooperation. (Data sources: from questionnaire survey and collection. See the Appendix for more details).

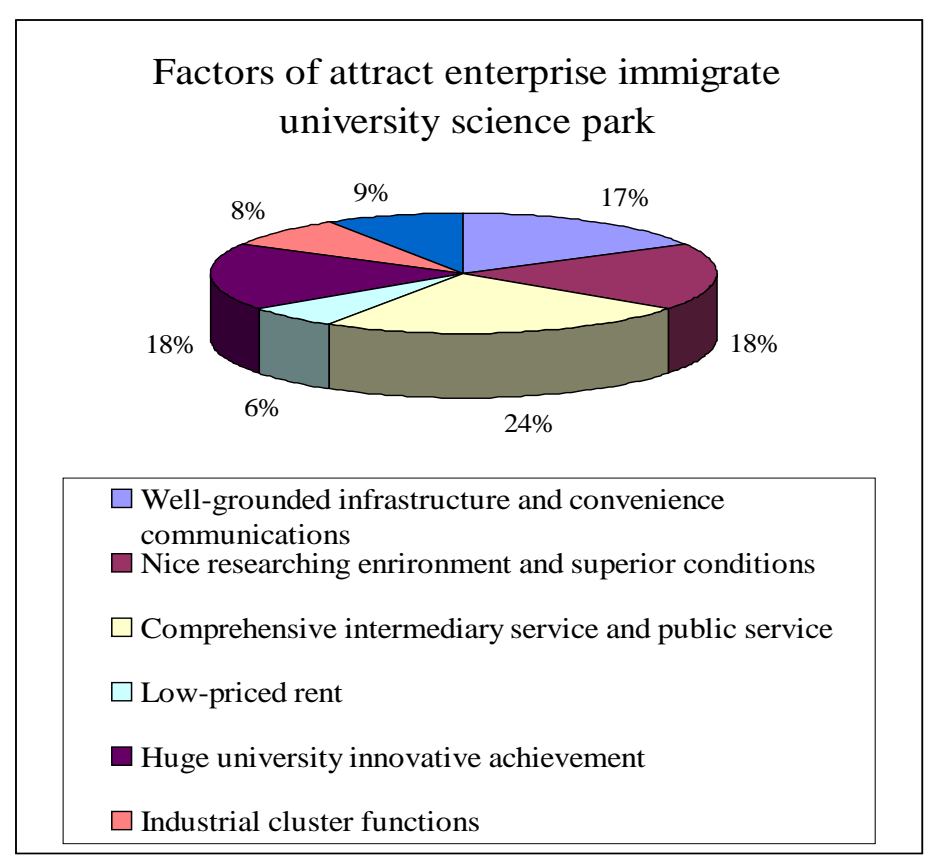

Figure 3. Factors of attract enterprise immigrate university science park. (Data sources: from questionnaire survey and collection. See the Appendix for more details). 
Figure 4 describes that "the Suggestions on Improving Public Service of University Science Park" from questionnaire collection. We got six points form data collection summary. You could see that the top three are as follows: “Accelerate development of public service platform”, account for 22\%. “Accelerate development of service system”, account for $21 \%$. "Improve service quality, add service content, creative service means, improve the service provider's quality”, account for $18 \%$. Some of the typical research responses are shown in Figure 4.

\section{Solution Recommendations}

University Science Parks of Gulou District are still at primary stage and has a lot of immature accepts. Policy support and guidance from the government is very important to it. And recommendations are as follows:

\subsection{Establish "Park Office" and Locate the Function}

Park Office can integrate the entire area resource with the platform and provide a series of services, which avoid the duplication of similar projects. And the function of them should be exactly located to program, coordinate, serve and manage.

Park Office should unify association and coordination of three national parks (contain DINGJIAQIAO district of Southeast University) and three provincial parks. And it should take the function such as programming of carrier construction, the coordination of infant industry cultivation, the service and propulsion of newly built Science and Technology Park, the construction of public services platform and so on [12].

\subsection{Build a Multi-Channel Fund-Raising Mechanism}

The abundant financing is the prerequisite for the sound development of Science Park. It includes three modes: government investment, risk investment and private investment.

It is necessary for the government to increase the investment on the construction of infrastructural facilities and public services platform through the direct budget, or investment on research or techniques through spe-

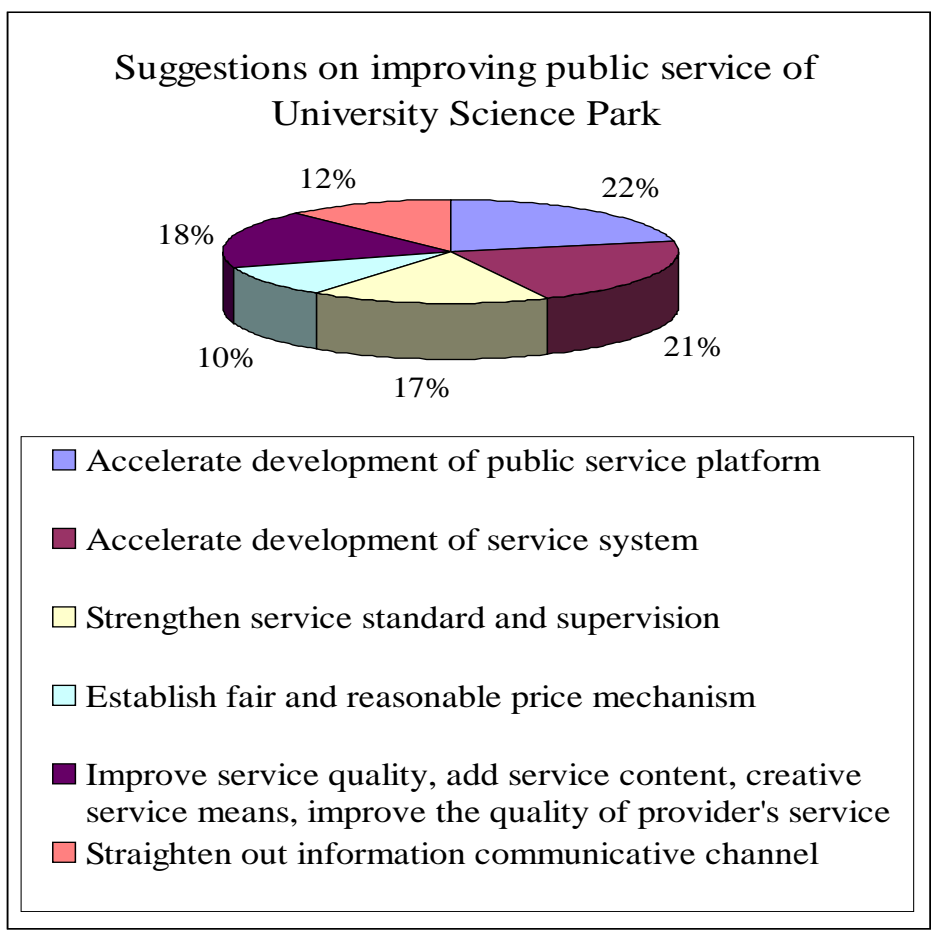

Figure 4. Suggestions on improving public service of university science park. (Data sources: from questionnaire survey and collection. See the Appendix for more details). 
cial-purpose funds; Setting up "financial club” in Nanjing Technological Square is a good way to perfect risk investment mechanism; Breaking the policy barrier and mobilizing private funds can amend fund conditions of University Science Park. Private funds derive from large company, private bank, insurance company, personal and some other organizations.

\subsection{Perfect Talent Training and Support System}

Taking "High-Level Creative Entrepreneurial Talent Introduction Scheme" as an opportunity, the formulating of the standard for introducing high-level talents from both home and abroad should led by the district government and joined by various University Science Parks and relevant universities. It's vital to acknowledge the importance of establishing the solid chain of "Talent-Program-Industry-Tax". The government and relevant departments should press ahead with and firmly through negotiation with universities. High-level entrepreneurial talents can also be hired as part-time professors at universities to help the universities drive academic building [13]. It's also practicable for the entrepreneurial talents to be appointed as full-time professors based on the agreement of universities after a certain period of time.

It will fall to the district government to give priority to the household registration of the high-level talents introduced and the supporting measures for their children to go to elite schools.

\subsection{Complete Innovation Platform and Service System}

Based on the requirements of the development of new strategic industries, the district government may integrate the academic strength, $R \& D$ and technological advantages of research institutions and enterprises. Combining the industrial relevance, the State University Science Park should focus on establishing a number of professional and technical innovation service platforms, public test platforms and open engineering research laboratories.

In addition, the government should offer the enterprises in the park with service and technical support from the perspective of investment and financing services, talent training, information services, intellectual property protection, technology transfer, technology development and product testing to promote sustainable development of University Science and Technology Park [14].

\section{Conclusion}

University Science Park, a newly emerging thing for urban economy, is a new form of innovation system. At present, targets of local government are to strengthen policy support, increase capital investment, provide good macro operational guidance and management, solve the problems of different management models with targeted countermeasures and do not require a unified development model. We firmly believe that in the next five to eight years, University Science Park in Gulou District will become a driving force to promote local economic development.

\section{Information about Authors}

Songqiang Wu is post-doctoral from Nanjing University, China (210009). He is an associate professor of Economic and Management School, Nanjing Technology University.

He has published several papers at Chinese high ranked referred Journals. Some of these referred journals are recognized authority magazines, like Science and Technology Management Research, Scientific Management Research, Enterprise Economy, Jiangsu Commercial Forum, Modern Education Management, Enterprise Economy, Asia-pacific Economic Review, Journal of Anhui Agricultural Sciences, China Business \& Trade, Enterprise Management, Science \& Technology Progress and Policy, Review of Economic Research and Ecological Economy.

Xiao Xiao is a master degree candidate of Administration in Nanjing University of Technology.

Wang Lu is a master degree candidate of Business Management in Nanjing University of Technology.

Yingyi Shen is a master degree candidate of Business Management in Nanjing University of Technology.

Xianting Tao is a master degree candidate of Business Management in Nanjing University of Technology.

\section{Project Funding}

National Social Science Foundation of China, "Small and Micro Businesses Horizontal Strategic Alliance and 
Innovative Performance Study” (13CGL044); Key Collaborative Projects under the National Soft Science Research Program (2013GXS2D024); “The 6th installment of” Special Program of China Postdoctoral Foundation (2013T60527); The 52 batch of National Post Doctoral Fund (2012M521055); The National Natural Science Fund (G030703); Jiangsu province colleges and universities "Blue Project” young Key Teacher Project (No. 1, 2014); 2014 Jiangsu provincial government scholarship studying abroad; National Social Science Foundation of China (14G030703).

\section{References}

[1] Yu, A.P. (2010) Research on the Status and Role of the University Science and Technology Park in the Economic Transformation of the Yangtze Delta Region. Journal of Science Development, 2, 68-74.

[2] Fu, Y. and Ma, Q. (2009) The Analysis on the Role of Local Government in Development of National University Science Park. R\&D Management, 21, 101-105.

[3] Wu, Q.F. and Wei, H.A. (2004) The Research on Building Efficient Management System of National University Science Park. Science \& Technology Progress and Policy, 10, 23-25.

[4] Tan, X.F., Zhu, X.Y., Wu, L.S. and Yan, L. (2013) Research on Assessment Index System of Contribution on Regional Economy by University Science Park. Science and Technology Management Research, 16, 67-72.

[5] Xia, J. and Tu, J. (2005) On the Building Standard of University Science and Technology Garden. Studies in Science of Science, 23, 204-207.

[6] Li, P. (1999) The Comparison of University Science Park Development Model. Studies in Science of Science, 4, 90-95.

[7] McAdama, M. and McAdam, R. (2008) High Tech Start-Ups in University Science Park Incubators: The Relationship between the Start-Up’s Life Cycle Progression and Use of the Incubator's Resources. Technovation, 28, 277-290. http://dx.doi.org/10.1016/j.technovation.2007.07.012

[8] Liu, C.L. and Peng, J.S. (2004) How to Set up a University Science Park?-An Empirical Study on the Science Park of Nanjing University. Journal of R\&D Management, 16, 101-107.

[9] Yin, Q., Xie, Y. and Chen, W.M. (2010) The Research on Incubation Performance of University Science Parks—Policy Analysis Perspective. China Soft Science Magazine, 3, 88-94.

[10] Zhang, W., Cheng J.Y., Gao, J. and Shi, S.D. (2009) The Development and Evaluation of University Based Science Park in China_An Example of the Zhongguancun Area. R\&D Management, 21, 95-101.

[11] Li, L., Xia, D.D. and Wang, Y. (2009) The Empirical Research on Optimizing Cooperating Mechanism of Industries, Universities and Research Institutes: Based on Construction of Chongqing Science Parks Evaluation Index System. Journal of Chongqing University (Social Science Edition), 15, 142-148.

[12] Dettwiler, P., Lindelvf, P. and Lvfsten, H. (2006) Utility of Location: A Comparative Survey between Small New Technology-Based Firms Located on and off Science Parks: Implications for Facilities Management. Technovation, 26 506-517. http://dx.doi.org/10.1016/j.technovation.2005.05.008

[13] Hansson, F., Husted, K. and Vestergaard, J. (2005) Second Generation Science Parks: From Structural Holes Jockeys to Social Capital Catalysts of the Knowledge Society. Technovation, 25, 1039-1049. http://dx.doi.org/10.1016/j.technovation.2004.03.003

[14] McAdam, R., Keogh, W., Galbraith, B. and Laurie, D. (2005) Defining and Improving Technology Transfer Business and Management Processes in University Innovation Center. Technovation, 25, 418-1429. http://dx.doi.org/10.1016/j.technovation.2004.08.002 


\section{Appendix}

\section{Questionnaire of the Current Situation of University Science Park in Gulou District of Nanjing China}

Hello, dear friend! In order to strengthen independent innovation, to promote the economy which is based on the inn-ovation, and to speed up regional economic transformation, would you like to spare a few seconds to answer these following questions in this questionnaire carefully and authentically! We will inform you that your answers will be kept strictly confidential! Thank you very much for your support and cooperation!

\section{Basic Situation}

1). University Name:

2). Your university's location:

3). The acreage about the University Science Park:

4). The amount of enterprises in incubation period:

5). The amount of Autonomous Intellectual property in the park near three years:

6). The amount of Scientific research projects in the park:

7). The amount of state laboratory:

8). Do you have Cooperate Partners in daily research projects?

And the amount of Cooperate Partners:

\section{The Features about the University Science Park}

\begin{tabular}{l} 
Characteristics about the University Science Park \\
\hline Industrial Direction: \\
Construction Feature: \\
Functional Orientation: \\
Development Model: \\
Operational Mechanism: \\
Present Difficulties: \\
Anticipated Work:
\end{tabular}

\section{The Current Situation of University Science Park}

1) . The financial resources of University science park:
A. Rental housing
B. Government grant
C. Educational training
D. Investment share of enterprise
E. Reward of enterprises incubation
F. Transformation of achievements
G. Intermediary service \& public service

2). What do you think of the difficulties of Industry, Academe and research Institutes Cooperation:

A. Lack of valuable research results

B. The intermediary capability and the level of scientific intermediary organization are undeveloped

C. The innovative consciousness of enterprises is weak and the enterprises have not enough R\&D funds

D. University scientific research system is restricted and the benefit allocation of Industry, Academe and research Institutes is too difficult.

E. Lack of government policy and risk investment

F. The index system of enterprises evaluation is defective

G. Large enterprises have monopolized the techniques and product technology

3). What do you think about the factors of attract enterprises immigrate university science park:

A. Well-grounded infrastructure and convenience communications 
B. Nice researching environment and superior conditions

C. Comprehensive intermediary and public service

D. Low-priced rent

E. Huge university innovative achievement

F. Industrial cluster functions

4). What's your suggestions on improving public service of university science park:

A. Accelerate development of public service platform

B. Accelerate development of service system

C. Strengthen service standard and supervision

D. Establish fair and reasonable price mechanism

E. Improve service quality, add service content, creative service means, improve the quality of provider's service

F. Straighten out information communicative channel 